\title{
KEBIJAKAN REFORMASI REGULASI MELALUI \\ IMPLEMENTASI OMNIBUS LAW DI INDONESIA
}

(Regulatory Reform Policy Through Implementation of Omnibus Law in Indonesia)

\author{
Ima Mayasari \\ Fakultas Ilmu Administrasi Universitas Indonesia \\ Gedung Prof. Dr. Mr. Prajudi Atmosudirdjo, \\ Komplek Fakultas IImu Sosial dan IImu Politik, Kampus UI Depok 16424 \\ e-mail: imamayasari@ui.ac.id
}

Naskah diterima: 15 Februari 2020; revisi: 3 April 2020; disetujui: 6 April 2020

\begin{abstract}
Abstrak
Kebijakan reformasi regulasi menjadi elemen kunci dalam reformasi administrasi publik Indonesia. Reformasi regulasi mengurangi hambatan terhadap daya saing dan keterbukaan pasar serta dinamika pasar untuk memastikan tercapainya kesejahteraan sosial. Implementasi Omnibus Law di Indonesia menjadi daya tarik bagi kalangan pengambil kebijakan, akademisi dan praktisi. Dalam iklim berusaha yang penuh dengan persaingan, kenyataan menunjukkan kondisi regulasi Indonesia sangat banyak (hyper regulation) dan tumpang tindih (overlap) antara satu dan yang lain, serta tidak sesuai lagi dengan keadaan era Revolusi Industri Keempat saat ini. Penelitian ini terfokus pada kebijakan reformasi regulasi melalui implementasi Omnibus Law di Indonesia, untuk mendeskripsikan implementasi Omnibus Law di Indonesia, sebagai sarana utama dalam penataan regulasi. Metode penelitian yang dipergunakan adalah penelitian hukum normatif. Hasil penelitian menunjukkan bahwa implementasi Omnibus Law penting untuk diterapkan di Indonesia, dan mampu untuk melakukan perubahan terhadap berbagai Undang-Undang dalam satu Undang-Undang.
\end{abstract}

Kata Kunci: Omnibus Law, reformasi regulasi, kebijakan publik

\begin{abstract}
Regulatory reform policy is a key element in Indonesia's public administration reform. Regulatory reforms reduce barriers to market competitiveness and openness and market dynamics to ensure social welfare is achieved. The implementation of the omnibus law in Indonesia is an attraction for policy makers, academics and practitioners. In a business climate filled with competition, the reality shows the conditions of Indonesia's regulations are very much (hyper regulation), overlap between one and another, and no longer in accordance with the current condition of the Industrial Revolution 4.0 era. This research focuses on the policy of regulatory reform through the implementation of the omnibus law in Indonesia, to describe the implementation of the omnibus law in Indonesia, as the main tool in structuring regulations, and seeing what will happen and what should be done in Omnibus Law. The research used normative legal research methode. The results showed that the implementation of the Omnibus Law was important to be applied in Indonesia, and was able to make changes to various laws in one law.
\end{abstract}

Keywords: Omnibus Law, regulatory reform, public policy 


\section{A. Pendahuluan}

Perdebatan mengenai Omnibus Law sebagai sarana utama untuk penataan regulasi, mengemuka ketika metode Omnibus Law yang sebelumnya tidak banyak dikenal di Indonesia-negara dengan sistem hukum Eropa Kontinental, menjadi digunakan dalam penyusunan Rancangan Undang-Undang (RUU) yang menjadi Program Legislasi Nasional Prioritas Tahun 2020. Terdapat dua RUU dalam Program Legislasi Nasional Prioritas Tahun 2020 yang menggunakan metode Omnibus Law yaitu: RUU tentang Cipta Kerja (Omnibus Law) yang diusulkan oleh Pemerintah dan RUU tentang Ketentuan dan Fasilitas Perpajakan untuk Penguatan Perekonomian (Omnibus Law) yang diusulkan oleh Pemerintah. ${ }^{1}$

Dua RUU yaitu RUU Cipta Kerja dan RUU Fasilitas Perpajakan yang penyusunannya menggunakan metode Omnibus Law menarik untuk diteliti lebih mendalam. Kedua RUU ini telah memperoleh Surat Persetujuan Presiden (Surpres) dan telah diajukan Presiden kepada Dewan Perwakilan Rakyat (DPR). ${ }^{2}$ Konteks memformulasi Omnibus Law dalam mengatasi hambatan ketidakharmonisan regulasi dan menciptakan regulasi yang responsif, menaruh harapan yang besar dalam upaya melakukan penataan regulasi di Indonesia.
Kebijakan reformasi regulasi melalui implementasi Omnibus Law di Indonesia, tentu bukan sebuah hal yang gegabah dilakukan pemerintah. Banyak pertimbangan yang dilakukan oleh pemerintah mengapa memilih metode Omnibus Law dalam melakukan reformasi regulasi yang mendesak untuk dilakukan. Berbagai upaya untuk mendorong peningkatan investasi dilakukan oleh pemerintah, namun di tengah era Revolusi Industri Keempat, berbagai kebijakan yang telah ditempuh oleh pemerintah untuk perbaikan iklim investasi masih belum memberikan ketertarikan bagi investor untuk menanamkan modalnya di Indonesia.

Salah satu penyebab keengganan investor untuk berinvestasi di Indonesia adalah sulitnya berusaha di Indonesia. ${ }^{3}$ Upaya terakhir yang dilakukan oleh pemerintah untuk meningkatkan kemudahan berusaha di Indonesia dengan langkah Presiden mengeluarkan Peraturan Presiden Nomor 91 Tahun 2017 tentang Percepatan Pelaksanaan Berusaha. ${ }^{4}$

Simplikasi dalam hal perizinan berusaha merupakan hal yang menjadi substansi utama dalam terbitnya Perpres Nomor 91 Tahun $2017,{ }^{5}$ yang kemudian menghasilkan sebuah terobosan kebijakan berupa Peraturan Pemerintah Nomor 24 Tahun 2018 tentang Pelayanan Perizinan Berusaha Terintegrasi Secara Elektronik-yang selanjutnya disebut

1 DPR, "Program Legislasi Nasional Prioritas Tahun 2020-2024", http://http://www.dpr.go.id/uu/prolegnas, diakses tanggal 15 Februari 2020).

2 Kontan, "Pemerintah Serahkan Surat Presiden dan Draft Omnibus Law RUU Cipta Kerja ke DPR", http://www. nasional.kontan.co.id/news/pemerintah-serahkan-surat-presiden-dan-draf-omnibus-law-ruu-cipta-kerja-kedpr (diakses tanggal 15 Februari 2020).

3 Tempo, "Sulitnya Berinvestasi di Indonesia", http://www.kolom.tempo.co/read/1143060/sulitnya-berinvestasidi-indonesia (diakses tanggal 15 Februari 2020).

4 Indonesia, Peraturan Presiden Nomor 91 Tahun 2017 tentang Percepatan Pelaksanaan Berusaha. Lembaran Negara Republik Indonesia Tahun 2017 Nomor 2010.

5 Ibid. 
Online Single Submission (OSS). ${ }^{6}$ Namun, kenyataan menunjukkan bahwa terbitnya PP Nomor 24 Tahun 2018, dengan simplifikasi bisnis proses OSS masih menemukan banyak kendala, selain belum menunjukkan hasil (outcomes) yang signifikan dan masih jauh dari harapan.

Dalam tulisannya, Pradany Hayyu mengemukakan bahwa investasi dunia terhadap Indonesia masih rendah yaitu 1,97 \% (satu koma sembilan puluh tujuh persen) dari rata-rata per tahun (2012-2016) sebesar USD $1,417,8$ miliar serta pencapaian target rasio investasi sebesar 32,7 persen (2012- 2016) yaitu di bawah target Rencana Pembangunan Jangka Menengah Nasional (RPJMN) sebesar
38,9 \% (tiga puluh delapan koma sembilan persen) pada tahun 2019. Pandangan Pradany Hayyu ini mengisyaratkan bahwa banyak hal yang masih perlu dilakukan pembenahan oleh pemerintah dalam iklim kemudahan berusaha. $^{7}$

Hal ini juga dibuktikan dengan indeks kemudahan berusaha (Ease of Doing Business/ EODB) Indonesia-yang digunakan untuk mengetahui respon pelaku usaha terhadap berbagai indikator, antara lain perizinan, regulasi, pelayanan publik, akses terhadap terhadap keuangan, dan jaminan kepastian hukum, sebagaimana tertuang dalam Tabel. 1.1. Peringkat Ease of Doing Business Tahun 2019/2020, berikut ini:

Tabel 1. Peringkat Ease of Doing Business Indonesia Tahun 2019/2020

\begin{tabular}{|c|c|c|c|c|c|c|}
\hline Indikator EoDB & $\begin{array}{c}\text { DB } 2020 \\
\text { Rank }\end{array}$ & $\begin{array}{c}\text { DB } 2019 \\
\text { Rank }\end{array}$ & Change & $\begin{array}{c}\text { DB } 2020 \\
\text { Score }\end{array}$ & $\begin{array}{c}\text { DB } 2019 \\
\text { Score }\end{array}$ & Change \\
\hline Starting a Business & 140 & 134 & -6 & 81,2 & 79,4 & $+1,8$ \\
\hline Dealing with Construction Permits & 110 & 112 & +2 & 66,8 & 65,9 & $+0,9$ \\
\hline Getting Electricity & 33 & 33 & 0 & 87,3 & 86,4 & $+0,9$ \\
\hline Registering Property & 106 & 100 & -6 & 60 & 60,1 & $-0,1$ \\
\hline Getting Credit & 48 & 44 & -4 & 70 & 70 & 0 \\
\hline Protecting Minority Investors & 37 & 51 & +14 & 70 & 70 & 0 \\
\hline Paying Taxes & 81 & 112 & +31 & 75,8 & 68,4 & $+7,4$ \\
\hline Trading across Borders & 116 & 116 & 0 & 67,5 & 66,5 & $+1,0$ \\
\hline Enforcing Contracts & 139 & 146 & +7 & 49,1 & 47,2 & $+1,9$ \\
\hline Resolving Insolvency & 38 & 36 & -2 & 68,1 & 67,9 & $+0,2$ \\
\hline TOTAL & 73 & 73 & 0 & 69,6 & 67,96 & $+1,64$ \\
\hline
\end{tabular}

Sumber: $E O D B, 2020^{8}$

6 Indonesia, Peraturan Pemerintah Nomor 24 Tahun 2018 tentang Pelayanan Perizinan Berusaha Terintegrasi Secara Elektronik. Lembaran Negara Republik Indonesia Tahun 2018 Nomor 90, Tambahan Lembaran Negara Republik Indonesia Nomor 6215.

7 Pradany Hayyu, "Sinyal Baik dalam Kemudahan Berusaha", Mediakeuangan (VOL. XIII / NO. 128 / Mei 2018), hlm. 17.

8 The World Bank, "Ease of Doing Business Rankings", https://www.doingbusiness.org/en/rankings(diakses tanggal 15 Februari 2019). 
Dari 10 indikator EoDB, yang meliputi: (1) Starting a Business; (2) Dealing with Construction Permits; (3) Getting Electricity; (4) Registering Property; (5) Getting Credit; (6) Protecting Minority Investors; (7) Paying Taxes; (8) Trading Across Borders; (9) Enforcing Contracts; dan (10) Resolving Insolvency, ${ }^{9}$ sebagaimana tersaji dalam Tabel. 1.1. di atas menunjukkan bahwa peringkat starting $a$ business Indonesia, pada tahun 2020 malah turun dari sebelumnya berada pada peringkat 134 turun 6 peringkat menjadi peringkat 140. Padahal, di tahun 2019 Indonesia sudah melaksanakan mekanisme OSS dalam perizinan berusaha yang terintegrasi secara elektronik, dengan diperkenalkannya Nomor Induk Berusaha (NIB). Indikator lain yang peringkatnya turun yaitu indikator registering property yang pada tahun sebelumnya berada pada peringkat 100, turun 6 peringkat menjadi berada di peringkat 106. Indikator Getting Credit juga turun dari sebelumnya berada pada peringkat 44 turun 4 peringkat menjadi berada di peringkat 48 .

Lebih lanjut indikator Resolving Insolvency juga turun dari sebelumnya berada pada peringkat 36 turun 2 peringkat menjadi berada di peringkat 38. Meskipun demikian, beberapa indikator yang mengalami peningkatan yaitu Dealing with Construction Permits; Protecting Minority Investors; Paying Taxes; dan Enforcing Contracts. Adapun indikator yang tidak mengalami perubahan peringkat terdapat pada indikator Getting Electricity dan Trading across Borders.
Berdasarkan perhitungan score untuk masing-masing indikator, maka diperoleh hasil bahwa peringkat EODB Indonesia jika dibandingkan pada tahun 2019 dan tahun 2020 adalah sama, yaitu berada di peringkat 73. Perbandingan peringkat EoDB Indonesia dari Tahun 2015 sampai dengan Tahun 2020, terlihat dalam Grafik 1. Peringkat EoDB Indonesia dari Tahun 2015 sampai Tahun 2020, sebagai berikut:

Grafik 1. Peringkat EODB Indonesia dari Tahun 2015 sampai Tahun 2020

\section{$\begin{array}{llllll}2015 & 2016 & 2017 & 2018 & 2019 & 2020\end{array}$}

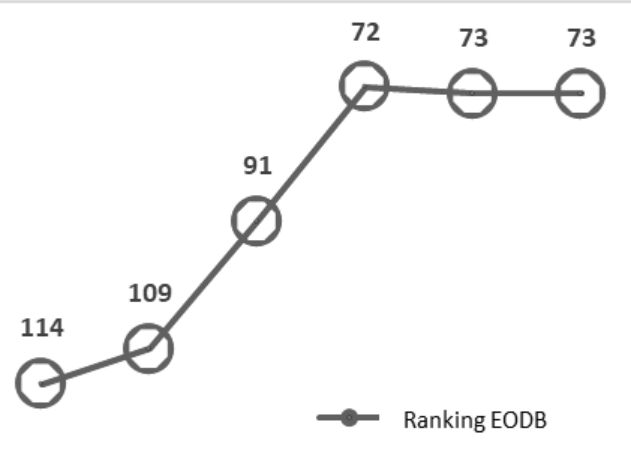

Sumber: Laporan EoDB, $2020^{10}$

Grafik 1 tersebut di atas menunjukkan adanya perbaikan peringkat EODB setiap tahunnya meningkat, namun demikian penurunan peringkat justru terjadi pada tahun 2019 dan 2020 yang lebih rendah satu peringkat dibandingkan pada tahun 2020.

Disisi lain, peringkat EODB Indonesia masih tertinggal dari negara serumpun lainnya yang menjadi peer group Indonesia. Peringkat EoDB Indonesia yang berada di bawah peer groupnya terlihat dalam Tabel 2. Rangking dan Skor

$9 \quad$ Ibid.

10 Kementerian Koordinator Bidang Perekonomian Republik Indonesia, Laporan Ease of Doing Business Tahun 2020. 
Ease of Doing Business Negara Serumpun, sebagai berikut: ${ }^{11}$

Tabel 2. Ranking dan Skor Ease of Doing Business Negara Serumpun

\begin{tabular}{ccc}
\hline Economy & $\begin{array}{c}\text { Ease of Doing } \\
\text { Business Rank }\end{array}$ & $\begin{array}{c}\text { Starting a } \\
\text { Business }\end{array}$ \\
\hline Singapore & 2 & 3 \\
\hline Malaysia & 15 & 122 \\
\hline Thailand & 27 & 39 \\
\hline Brunei Darussalam & 55 & 16 \\
\hline Vietnam & 69 & 104 \\
\hline Indonesia & 73 & 134 \\
\hline
\end{tabular}

Sumber: https://www.doingbusiness.org/en/rankings.

Tabel 1.2 di atas mengisyaratkan bahwa peringkat kemudahan berusaha dan starting a business di Indonesia masih berada di bawah negara serumpun seperti Singapura, Malaysia, Thailand, Brunei Darussalam, dan Vietnam. Dalam hal ini ekonomi diberikan peringkat berdasarkan kemudahan berusaha, dari 1-190. ${ }^{12}$ Kemudahan dalam melakukan usaha berarti lingkungan regulasi lebih kondusif untuk memulai dan mengoperasikan perusahaan.
Permasalahan yang menjadi penyebab Indonesia memiliki peringkat kemudahan berusaha yang berada di bawah negara peer group, antara lain terlihat dari beberapa indikator seperti kerumitan dalam memulai usaha (starting a business), pengadaan lahan yang sulit dan terlalu berbelit prosesnya (registering property), kesulitan yang dihadapi dalam memperoleh pembiayaan (getting credit), rumitnya penyelesaian dalam perkara kepailitan (resolving insolvency), yang menjadikan peringkat EODB Indonesia rendah. Oleh karena itu, perlu dilakukan strategi yang tepat dalam perbaikan iklim investasi Indonesia ke arah yang lebih baik.

Di sisi lain, berdasarkan Laporan Global Competitiveness Index, khususnya pada Pilar Institution, indikator Burden of Government Regulation pada sub pilar Public Sector Performance. Sub pilar ini mengalami penurunan, baik dari segi peringkat maupun skor. Indikator ini menunjukkan bahwa regulasi yang dikeluarkan oleh pemerintah ternyata justru menjadi beban. Padahal efisiensi birokrasi adalah modal utama untuk meningkatkan kepercayaan asing berinvestasi di Indonesia.

Tabel 3. Peringkat dan Skor Pilar Institusi pada GCI 2018/2019

\begin{tabular}{|l|c|c|c|c|}
\multirow{2}{*}{\multicolumn{1}{c|}{ Pilar, Sub Pilar, Indikator }} & \multicolumn{2}{c|}{ Peringkat } & \multicolumn{2}{c|}{ Skor } \\
\cline { 2 - 5 } & 2018 & 2019 & $\mathbf{2 0 1 8}$ & 2019 \\
\hline Pilar 1: Institution & 48 & $\mathbf{5 1}$ & $\mathbf{5 7 . 9}$ & $\mathbf{5 8 . 1}$ \\
\hline Sub Pilar: Security & 63 & 62 & 76.99 & 77.2 \\
\hline Sub Pilar: Social Capital & 10 & 12 & 63 & 63.2 \\
\hline Sub Pilar: Check and Balances & 52 & 39 & 55.16 & 57.2 \\
\hline Sub Pilar: Public Sector Performance & 38 & 54 & 56.45 & 54.6 \\
\hline
\end{tabular}

11 The World Bank,op.cit.

12 Ibid. 


\begin{tabular}{|c|c|c|c|c|}
\hline Burden of government regulation & 26 & 29 & 52.01 & 50.8 \\
\hline Efficiency of legal framework to settle disputes & 46 & $55 \downarrow$ & 51.98 & 51.1 \\
\hline E-Participation Index (0-1, best) & 88 & 89 & 61.8 & 61.8 \\
\hline Sub Pilar: Transparency & 80 & 77 & 37 & 38,0 \\
\hline Sub Pilar: Property Rights & & 60 & & 56,4 \\
\hline Sub Pilar: Future orientation of government & - & 68 & - & 68 \\
\hline
\end{tabular}

Sumber: GCI 2019, World Economic Forum. ${ }^{13}$

Rumit atau sulitnya berinvestasi di Indonesia berimplikasi pada rendahnya daya saing Indonesia dibandingkan negara tetangga. Kerumitan atau sulitnya berinvestasi, menjadikan perlunya terobosan dalam reformasi regulasi di Indonesia, melalui adopsi terhadap metode Omnibus Law dalam penataan regulasi. Metode ini tentunya berbeda halnya dengan metode yang seringkali digunakan untuk mengubah satu per satu Undang-Undang, sementara yang akan dilakukan perubahan dengan penataan regulasi melalui Omnibus Law ini sekitar 80 (delapan puluh) Undang-Undang. Satu Undang-Undang yang mengubah berbagai ketentuan yang diatur dalam berbagai Undang-Undang, menjadi inti dari penggunaan metode Omnibus Law.

Omnibus Law merupakan sebuah praktik penyusunan peraturan perundang-undangan, yang banyak dilakukan di negara-negara yang menganut sistem Common Law/Anglo Saxon seperti Amerika, Kanada, Inggris, Filipina dan lainnya. Prosesnya disebut Omnibus Legislating dan produknya disebut Omnibus Bill. Frasa Omnibus berasal dari bahasa latin yang artinya segalanya atau semuanya (for everything).

Omnibus Law merupakan metode untuk membuat sebuah regulasi atau UndangUndang yang terdiri atas banyak subyek atau materi pokok untuk tujuan tertentu guna menyimpangi suatu norma peraturan. Omnibus Law berbeda dengan rancangan peraturan kebanyakan dalam hal jumlah materi muatan yang dicakup, banyaknya pasal yang diatur (ukuran), dan terakhir dari sisi kompleksitas. Sebuah Omnibus Law mencakup hampir semua substansi materi yang berhubungan-yang mencerminkan integrasi, kodifikasi peraturan yang tujuan akhirnya adalah untuk mengefektifkan penerapan peraturan tersebut. Metode legislasi Omnibus Law dari segi teoritis maupun praktis masih belum terlalu dikenal di Indonesia.

Berbagai teknik/metode pembentukan peraturan perundang-undangan serupa yang telah cukup populer di Indonesia contohnya adalah Regulatory Impact Assessment (RIA) dan Rule, Opportunity, Capacity, Communication, Interest, Process, Ideology (ROCCIPI). Merupakan suatu hal yang lazim

13 World Economic Forum, "The Global Competitiveness Report 2019", http://www3.weforum.org/docs/WEF_ TheGlobalCompetitivenessReport2019.pdf(diakses tanggal 15 Februari 2020). 
dalam pembentukan Undang-Undang ketika terdapat norma dalam peraturan perundangundangan yang dihasilkan melalui metode legislasi yang menghapus atau mengubah satu norma dan mengaturnya kembali dalam Undang-Undang yang dibentuk. Namun demikian mengingat metode legislasi Omnibus Law yang demikian masih sangat jarang dipraktikkan di Indonesia, maka Penelitian mengenai Kebijakan Reformasi Regulasi melalui Implementasi Omnibus Law di Indonesia menjadi penting.

Dalam hal, terdapat norma dalam peraturan perundang-undangan yang dihasilkan melalui metode legislasi menghapus atau mengubah satu norma dan mengaturnya kembali dalam Undang-Undang yang dibentuk adalah suatu hal yang lazim dalam pembentukan Undang-Undang. Kajian dan penelitian yang dilakukan tidak saja memastikan bahwa penggunaan metode legislasi Omnibus Law dalam pembentukan Rancangan Peraturan Perundang-Undangan mampu menata dan mengharmoniskan dan menciptakan simplifikasi peraturan perundang-undangan.

Dalam penyusunan suatu peraturan dengan metode Omnibusakan mencakup hampir semua substansi materi yang berhubungan sehingga peraturan tersebut dapat berdiri sendiri dan tidak bergantung dengan peraturan lain. Peraturan dengan metode omnibus mencerminkan sebuah integrasi, kodifikasi peraturan dimana tujuan akhirnya adalah untuk mengefektifkan penerapan peraturan tersebut di lapangan praktik. Omnibus Law atau sering disebut juga Omnibus Bill Adalah:

1. A single bill containing various distinct matters, usu. drafted in this way to force the executive either to accept all the unrelated minor provisions or to veto the major provisions.

2. A bill that deals with all proposals relating to a particular subject, such as an "omnibus judgeship bill" covering all proposals for new judgeships or an "omnibus crime bill" dealing with different subjects such as new crimes and grams to states for crime control. ${ }^{14}$

Pendapat serupa juga dinyatakan, bahwa Omnibus Law atau Omnibus Bill:

Just like a standard bill, omnibus bills are formal proposals to change laws that are voted on by rank and file lawmakers and sent off to the executive branch for final approval. The difference with omnibus bills is they contain numerous smaller bills, ostensibly on the same broad topic. Take the omnibus tax bill as an example: It may include changes on everything from income, corporate, and sales taxes, but all of those issues can fit under the large umbrella of taxes. ${ }^{15}$

Secara sederhana pandangan mengenai Omnibus Law di atas diterjemahkan bahwa Omnibus Law atau Omnibus Bill adalah satu Undang-Undang yang dapat mengubah banyak Undang-Undang. Berdasarkan halhal tersebut di atas, penelitian ini terfokus pada Kebijakan Reformasi Regulasi melalui Implementasi Omnibus Law di Indonesia, dengan perumusan masalah dalam penelitian yaitu: Bagaimana kebijakan reformasi regulasi melalui implementasi Omnibus Lawdi Indonesia?

14 Bryan A. Garner, ed., "Black's Law Dictionary", (Minnesota: West Publishing Co, 2004), hlm. 175.

15 Briana Bierscbach, "Everything You Need to Know About Omnibus Bills, and Why They"re So Popular at The Minnesota Legislature", https://www.minnpost.com/politics-policy/2017/03/everything-you-need-knowabout-omnibus-bills-and-why-theyre-so-popular-minne (diakses pada 22 Juli 2019). 


\section{B. Metode Penelitian}

Penelitian ini merupakan penelitian hukum normatif (normative legal research) dengan menggunakan pendekatan yuridis normatif (normative legal research). ${ }^{16}$ Datadata penelitian dikumpulkan melalui studi kepustakaan, dengan mengumpulkan dan menganalisa berbagai bahan hukum primer, bahan hukum sekunder dan bahan hukum tersier yang tersedia. ${ }^{17}$ Bahan hukum primer yaitu norma dasar atau kaidah, ketentuan atau peraturan dasar serta peraturan perundangundangan serta bahan hukum sekunder yaitu bahan hukum yang memberikan penjelasan lebih lanjut mengenai bahan hukum primer berupa literatur, artikel jurnal, dan juga hasil penelitian yang relevan.

Pengambilan data dilakukan dengan studi pustaka terhadap buku, artikel, hasil penelitian dan peraturan perundang-undangan. Analisis data dilakukan secara deskriptif kualitatif dalam melakukan pembahasan terhadap rumusan permasalahan penelitian.

\section{Pembahasan}

Omnibus Law merupakan metode yang tepat dalam menyusun payung hukum proses bisnis perizinan di Indonesia karena melalui metode Omnibus Law dapat membuat suatu regulasi mencakup lebih dari satu materi substantif, atau beberapa halkecil yang telah digabungkan menjadi satu aturan, yang bertujuan untuk menciptakan ketertiban, kepastian hukum dan kemanfaatan.
Metode Omnibus Law mampu melakukan perubahan, pencabutan, atau pemberlakukan beberapa karakteristik dari sejumlah fakta yang terkait tapi terpisahkan oleh peraturan perundang-undangan dalam berbagai lingkup yang diaturnya. Keberadaan RUU Cipta Kerja didesain sebagai Omnibus Law yang dapat menyeimbangkan antara ketiga tipe umum regulasi yaitu: Pertama, economic regulation, dimaksudkan untuk memastikan efisiensi pasar, sebagian melalui promosi daya saing yang memadai di antara para pelaku usaha. Kedua, social regulation, dimaksudkan untuk mempromosikan internalisasi semua biaya yang relevan oleh aktor. Ketiga, administrative regulation, yang bertujuan untuk memastikan berfungsinya operasi sektor publik dan swasta. ${ }^{18}$

Dengan mengacu pada Self Regulatings System, pemberian kewenangan yang tinggi kepada Presiden untuk mengatur regulasi bagi dirinya sendiri. Kekuasaan Presiden dalam membuat regulasi, dilakukan untuk melakukan pengatura baik pada economic regulation, social regulation maupun administrative regulation. RUU Cipta Kerja (Omnibus Law) disusun dengan pertimbangan untuk mendukung cipta kerja dimana diperlukan penyesuaian berbagai aspek pengaturan dimana perubahan Undang-Undang sektoral secara parsial dirasakan tidak efektif dan efisien, sehingga diperlukan terobosan hukum melalui pembentukan Undang-Undang dengan menggunakan metode Omnibus Law yang dapat menyelesaikan berbagai

\footnotetext{
16 Soerjono Soekanto dan Sri Mamudji, Penelitian Hukum Normatif: Suatu Tinjauan Singkat, Cet. 8 (Jakarta: PT RajaGrafindo Persada, 2006).

17 Johny Ibrahim, Teori dan Metodologi Penelitian Hukum Normatif, (Malang: Bayumedia Publishing, 2006), hlm.295.

18 OECD, "Regulatory Reform and Innovation", http://www.oecd.org sti/inno/2102514.pdf, hlm. 11 (diakses tanggal 15 Februari 2020).
} 
permasalahan dalam beberapa UndangUndang ke dalam satu Undang-Undang secara komprehensif. ${ }^{19}$

Kebijakan strategis Cipta Kerja memuat kebijakan penciptaan atau perluasan lapangan kerja melalui pengaturan yang terkait dengan: (a) peningkatan ekosistem investasi dan kegiatan berusaha; (b) peningkatan perlindungan dan kesejahteraan pekerja; (c) kemudahan, pemberdayaan, dan perlindungan UMK-M serta perkoperasian; dan (d) peningkatan investasi pemerintah dan percepatan proyek strategis nasional. Setidaknya terdapat sepuluh Ruang lingkup yang diatur dalam RUU Cipta Kerja, meliputi: (1) peningkatan ekosistem investasi dan kegiatan berusaha; (2) ketenagakerjaan; (3) kemudahan, perlindungan, dan pemberdayaan, UMK-M serta perkoperasian; (4) kemudahan berusaha; (5) dukungan riset dan inovasi; (6) pengadaan lahan; (7) kawasan ekonomi; (8) investasi Pemerintah Pusat dan percepatan proyek strategis nasional; (9) pelaksanaan administrasi pemerintahan; dan (10) pengenaan sanksi. ${ }^{20}$ Masing-masing dari sepuluh ruang lingkup pengaturan tersebut, memiliki cakupan Undang-Undang sektoral yang dilakukan Omnibus Law. Dalam hal ini kurang lebih 80 (delapan puluh) UndangUndang yang dilakukan Omnibus Law, dikelompokkan ke dalam Ruang Lingkup tersebut. Hal yang menarik berkaitan dengan peningkatan ekosistem investasi dan kegiatan berusaha yang meliputi: (a) penerapan Perizinan Berusaha berbasis risiko; (b) penyederhanaan persyaratan dasar
Perizinan Berusaha dan pengadaan lahan; (c) penyederhanaan Perizinan Berusaha sektor; dan (d). penyederhanaan persyaratan investasi. $^{21}$

Reformasi regulasi perizinan berusaha terlihat dalam ruang lingkup atau klaster peningkatan ekosistem investasi dan kegiatan berusaha dengan beberapa kebijakan utama yang diubah, salah satunya penerapan perizinan berusaha berbasis risiko (risk-based approach) yang mengadopsi best practice international berkaitan dengan perizinan berusaha, sebut saja apa yang sudah dilakukan oleh negara Inggris. Dengan demikian terjadi pergeseran dari licensing approach menjadi risk-based approach dalam perizinan berusaha. Perizinan Berusaha berbasis risiko dilakukan berdasarkan penetapan tingkat risiko kegiatan usaha. Penetapan tingkat risiko diperoleh berdasarkanperhitungan (a) nilai tingkat bahaya dan (b) nilai potensi terjadinya bahaya. ${ }^{22}$

Kemajuan reformasi bisnis perizinan berusaha dalam regulasi yang dibuat dengan metode Omnibus Law ini tentunya mendapat perhatian yang sangat positif, mengingat selama ini pendekatan perizinan (licensing approach) dirasa tidak efektif dan sudah ketinggalan zaman. Hal ini juga menjadikan investor enggan untuk menanamkan investasinya di Indonesia, karena perizinan berbelit-belit dan seringkali memunculkan praktik korupsi.

Dalam melakukan penilaian tingkat bahaya, dilakukan terhadap aspek kesehatan; keselamatan; lingkungan; dan/atau

\footnotetext{
19 Rancangan Undang-Undang Republik Indonesia tentang Cipta Kerja.

20 Ibid.

21 Ibid.

22 Ibid.
} 
pemanfaatan sumber daya. Untuk kegiatan tertentu, penilaian tingkat bahaya dapat mencakup aspek lainnya sesuai dengan sifat kegiatan usaha. Penilaian tingkat bahaya kegiatan usaha dilakukan dengan memperhitungkan: jenis kegiatan usaha; kriteria kegiatan usaha; lokasi kegiatan usaha; dan/atau keterbatasan sumber daya. Penilaian selanjutnya yang dilakukan terhadap potensi terjadinya bahaya meliputi: tidak pernah terjadi; jarang terjadi; pernah terjadi; atau sering terjadi. Berdasarkan penilaian tingkat bahaya dan penilaian atas potensi terjadinya bahaya, tingkat risiko kegiatan usaha ditetapkan menjadi: (a) kegiatan usaha berisiko rendah; (b) kegiatan usaha berisiko menengah; atau (c) kegiatan usaha berisiko tinggi. ${ }^{23}$

Pertama, perizinan berusaha untuk kegiatan berisiko rendah dilakukan melalui pemberian Nomor Induk Berusaha (NIB) yang menjadi legalitas pelaksanaan kegiatan berusaha. NIB merupakan bukti registrasi/ pendaftaran Pelaku Usaha untuk melakukan kegiatan usaha dan sebagai identitas bagi Pelaku Usaha dalam pelaksanaan kegiatan usahanya. ${ }^{24}$ Kedua, perizinan berusaha untuk kegiatan berusaha berisiko menengah dilakukan berupa pemberian NIB dan Sertifikat Standar. Sertifikat standar dalam hal ini merupakan pernyataan pemenuhan standar pelaksanaan kegiatan usaha yang wajib dipenuhi oleh Pelaku Usaha sebelum melakukan kegiatan usahanya.Ketiga, perizinan berusaha untuk kegiatan usaha berisiko tinggi, yang dilakukan berupa pemberian NIB dan Izin. Dalam hal ini izin merupakan persetujuan Pemerintah Pusat untuk melaksanakan kegiatan usaha yang wajib dipenuhi oleh pelaku usaha sebelum melaksanakan kegiatan usahanya. ${ }^{25}$

Hal penting lainnya dalam pelaksanaan penerapan perizinan berusaha berbasis risiko (risk-based approach) adalah pengawasan terhadap setiap kegiatan usaha yang dilakukan dengan intensitas pelaksanaan berdasarkan tingkat risiko kegiatan usaha. Adanya inspeksi atau pengawasan ini menjadi kunci keberhasilan dalam penerapan perizinan berusaha berbasis risiko, sebuah bisnis proses baru perizinan berusaha yang mengadaptasi perkembangan praktik bisnis berusaha di tataran internasional. Lebih lanjut pengaturan mengenai perizinan berusaha berbasisi risiko dan tata cara pengawasan diatur lebih lanjut dengan Peraturan Pemerintah. Dari hal ini saja, dapat dicermati secara mendalam bahwa RUU Cipta Kerja yang merupakan Omnibus Law membutuhkan kedetailan pengaturan dalam peraturan pelaksanaan. ${ }^{26}$

Hal lain yang masih berkaitan dengan klaster peningkatan ekosistem investasi dan kegiatan berusaha adalah penyederhanaan persyaratan dasar perizinan berusaha dan pengadaan lahan yang meliputi: kesesuaian kegiatan pemanfaatan ruang, persetujuan lingkungan dan persetujuan bangunan gedung dan sertifikat laik fungsi. Aturan yang mendorong kepastian berusaha bagi investasi adalah kesesuaian kegiatan pemanfaatan ruang yang merupakan kesesuaian rencana

\footnotetext{
Ibid.

Ibid.
}

25 Ibid.

26 Ibid. 
lokasi kegiatan dan/atau usahanya dengan Rencana Detail Tata Ruang (RDTR). ${ }^{27}$

Dalam hal ini Pemerintah Daerah memiliki kewajiban untuk menyusun dan menyediakan RDTR dalam bentuk digital yang sesuai dengan standar an dapat diakses dengan mudah oleh masyarakat untuk mendapatkan informasi mengenai kesesuaian rencana lokasi kegiatan dan/atau usahanya dengan RDTR. Pemerintah Pusat wajib mengintegrasikan RDTR dalam bentuk digital kedalam sistem Perizinan Berusaha secara elektronik. $^{28}$

Pelaku Usaha mendapatkan informasi rencana lokasi kegiatan usahanya telah sesuai dengan RDTR, Pelaku Usaha mengajukan permohonankegiatan pemanfaatan ruang untuk kegiatan usahanya melalui Perizinan Berusaha secara elektronikuntuk memperoleh konfirmasi kesesuaian kegiatan pemanfaatan ruang. Setelah memperoleh konfirmasi kesesuaian kegiatan pemanfaatan ruang, Pelaku Usaha dapat langsung melakukan kegiatan usahanya. Pengecualian pengaturan diberikan dalam hal Pemerintah Daerah belum menyusun dan menyediakan RDTR, Pelaku Usaha mengajukan permohonan persetujuan kesesuaian kegiatan pemanfaatan ruang untuk kegiatan usahanya kepada Pemerintah Pusat melalui Perizinan Berusaha secara elektronik sesuai dengan ketentuan peraturan perundang-undangan.

Pemerintah Pusat dalam memberikan persetujuan kesesuaian kegiatan pemanfaatan ruang dilakukan sesuai dengan rencana tata ruang. Rencana tata ruang terdiri atas: (a) Rencana Tata Ruang Wilayah Nasional (RTRWN); (b) Rencana Tata Ruang Pulau/Kepulauan;(c) Rencana Tata Ruang Kawasan Strategis Nasional; (d) Rencana Tata Ruang Wilayah Provinsi; (e) Rencana Tata Ruang Wilayah Kabupaten/Kota; dan/atau (f) Rencana Tata Ruang atau Rencana Zonasi lainnya yang ditetapkan Pemerintah Pusat. ${ }^{29}$ Berkaitan dengan persetujuan lingkungan, dalam rangka memberikan kemudahan bagi pelaku usaha dalam memperoleh persetujuan lingkungan, RUU Cipta Kerja (Omnibus Law) mengubah, menghapus, atau menetapkan pengaturan baru beberapa ketentuan terkait Perizinan Berusaha yang diatur dalam Undang-Undang Nomor 32 Tahun 2009 tentang Perlindungan dan Pengelolaan Lingkungan Hidup. Lebih lanjut berkaitan dengan Persetujuan Bangunan Gedung dan Sertifikat Laik Fungsi, Untuk memberikan kemudahan bagi masyarakat terutama Pelaku Usaha dalam memperoleh Persetujuan Bangunan Gedung dan Sertifikat Laik Fungsi Bangunan, RUU Cipta Kerja (Omnibus Law) ini mengubah, menghapus, atau menetapkan pengaturan baru beberapa ketentuan yang diatur dalam: Undang-Undang Nomor 28 Tahun 2002 tentang Bangunan Gedung dan Undang-Undang Nomor 6 Tahun 207 tentang Arsitek. ${ }^{30}$

Sejatinya, Omnibus Law merupakan sebuah praktik penyusunan peraturan perundang-undangan, yang banyak dilakukan di negara-negara yang menganut sistem common law (anglo saxon) seperti Amerika, 
Kanada, Inggris, Filipina dan lainnya. Namun, hal tersebut tidak menutup kemungkinan di negara yang menganut sistem civil law (continental). Vietnam adalah negara civil law yang berhasil menerapkan omnibus law pada tahun 2016. Hasil penelitian menunjukan bahwa Vietnam dimungkinkan untuk menerapkan Omnibus Law mengingat tidak terdapat peraturan perundang-undangan yang melarang. Selain itu, adanya tumpang tindih peraturan dan panjangnya prosedur legislasi untuk mengubah sebuah peraturan, menjadi pertimbangan diadopsinya Omnibus Law di Vietnam.

Omnibus Law yang berhasil dibentuk oleh Vietnam diantaranya Law Amending and Supplementing a Number of Articles of the Law on Value-Added Tax, the Law on Excise Tax and the Law on Tax Administration, UndangUndang ini mengubah, menambahkan serta mencabut beberapa pasal yang terdapat pada Undang-Undang Pertambahan Nilai Pajak, Undang-Undang Pajak Cukai, dan UndangUndang Administrasi Perpajakan. Terdapat pula, Law Amending and Supplementing a Number of Articles of the Laws on Taxes yang mengubah, menambahkan serta mencabut beberapa pasal yang ada pada UndangUndang Pajak Penghasilan Badan usaha, Undang-Undang Pertambahan Nilai Pajak, Undang-Undang Pajak Royalti, UndangUndang Pajak Cukai, dan Undang-Undang Administrasi Perpajakan, dan Undang-Undang Pajak Ekspor-Impor.

Pada tataran implementatif, kebutuhan penerapan Omnibus Law di Indonesia sangat mendesak. Hal ini mengingat tidak terintegrasinya perizinan berusaha di Indonesia secara baik, yaitu peraturan dan kewenangan yang tumpang tindih dan tidak harmonis, serta prosedur perizinan berusaha yang berbelit-belit. Oleh karena itu, diperlukan instrumen hukum yang mampu mensimplifikasi, men-deregulasi, dan restrukturisasi perizinan berusaha di Indonesia.

Berdasarkan pengalaman penerapan Omnibus Law di negara lain utamanya negara civil law, tidak tertutup kemungkinan bagi Indonesia untuk menerapkan metode baru penyusunan peraturan tersebut. Dari perspektif hukum, tidak ditemukan peraturan perundang-undangan yang menghalangi penerapan Omnibus Law di Indonesia, apabila dikaitkan dengan Undang-Undang Nomor 12 Tahun 2011 tentang Pembentukan Peraturan Perundang-Undangan sebagaimana diubah dengan Undang-Undang Nomor 15 Tahun 2019, secara yuridis formil penerapan konsep Omnibus Law relevan untuk diterapkan di Indonesia. Semangat Omnibus Law untuk mensimplifikasi, mederegulasi, dan restrukturisasi perizinan berusaha sejalan dengan asas pembentukan peraturan perundang-undangan sebagaimana ditetapkan dalam Undang-Undang Nomor 12 Tahun 2011 sebagaimana diubah dengan Undang-Undang Nomor 15 Tahun 2019.

Selanjutnya, berdasarkan pengalaman, Indonesia juga pernah mengeluarkan peraturan yang mengandung sifat Omnibus Law, seperti Ketetapan MPR RI Nomor I/ MPR/2003 tentang Peninjauan terhadap Materi dan Status Hukum Ketetapan MPR Sementara dan Ketetapan MPR RI tahun 1960 yang mengatur perihal TAP MPR apa saja yang dinyatakan berlaku dan tidak berlaku; penggabungan beberapa materi muatan undang-undang yang diatur dalam UUD Negara Republik Indonesia Tahun 
1945, seperti Undang-Undang Nomor 23 Tahun2014 tentang Pemerintahan Daerah yang berdampak mencabut Undang-Undang Nomor 5 Tahun 1962 tentang Perusahaan Daerah, dan Undang-Undang Nomor 32 Tahun 2004 tentang Pemerintahan Daerah, UndangUndang Nomor 28 Tahun 2009 tentang Pajak dan Retribusi Daerah; Undang-Undang Nomor 17 Tahun 2014 tentang MPR, DPR, DPD, DPRD. Demikian halnya Undang-Undang Nomor 13 Tahun 2003 tentang Ketenagakerjaan yang mencabut 6 Ordonansi dan 9 UndangUndang dan Peraturan Pemerintah Pengganti Undang-Undang Nomor 1 Tahun 2017 tentang Akses Informasi Keuangan untuk Kepentingan Perpajakan yang menyatakan tidak berlaku Pasal 35 ayat (2) dan Pasal 35A Undang-Undang Nomor 6 Tahun 1983 beserta perubahannya; Pasal 40 dan Pasal 41 Undang-Undang Nomor 7 Tahun 1992 beserta perubahannya; Pasal 47 Undang-Undang Nomor 8 Tahun 1995; Pasal 17, Pasal 27, dan Pasal 55 Undang-Undang Nomor 31 Tahun 1997 beserta perubahannya; serta Pasal 41 dan Pasal 42 Undang-Undang Nomor 21 Tahun 2008.

Selanjutnya, laju perkembangan teknologi yang semakin pesat membuat setiap negara terus mengembangkan atau memperbarui aturan hukum yang berlaku terutama sektor berusaha. Tak terkecuali bagi Indonesia yang perlu melakukan perbaikan regulasi agar dapat bersaing dan terintegrasi dengan perekonomian dunia sehingga dapat mewujudkan kesejahteraan sosial.

Dewasa ini, pembuatan atau perubahan hingga disahkannya suatu regulasi memakan waktu yang cukup lama. Berdasarkan Undang-
Undang Nomor 12 Tahun 2011 sebagaimana diubah dengan Undang-Undang Nomor 15 Tahun 2019, untuk membentuk atau mengubah satu peraturan diperlukan tahapan: persiapan dan perancangan; pembahasan atau pembicaraan; pengesahan atau penetapan; dan pengundangan atau pengumuman. Di sisi lain, kehidupan di era modern dinamis dan diiringi perkembangan laju teknologi yang serba cepat, yang memungkinkan adanya urgensi untuk mengubah atau membentuk banyak regulasi dalam waktu yang singkat. Oleh karena itu, kita membutuhkan akselerasi dan inovasi dalam proses penyusunan peraturan perundang-undangan yang lebih efektif dan efisien.Omnibus Law ini akan mengakselerasihambatan dari aturan yang tumpang tindih ini, sehingga kepastian berusaha dapat dijamin khususnya kepada investor yang akan menanamkan modalnya di Indonesia. ${ }^{31}$

\section{Penutup}

Berdasarkan hal-hal tersebut di atas dapat disimpulkan bahwa dengan adanya penyusunan RUU Cipta Kerja sebagai Omnibus Law, dimana Undang-Undang ini akan melakukan perubahan, pencabutan, atau pemberlakukan beberapa ketentuan yang terdapat pada beberapa aturan pada tingkatan yang berbeda ke dalam suatu peraturan perundang-undangan, sehingga akan menghasilkan suatu peraturan yang bersifat khusus yakni terkait perizinan berusaha yang akan menyelesaikan panjangnya rantai birokrasi, peraturan yang tumpang tindih

31 Ima Mayasari, "Menggagas Omnibus Law", https://kumparan.com/dr-ima-mayasari-m-h/menggagas-omnibuslaw-1542018891459839175, (diakses pada 22 Juli 2019). 
lintas kementerian, ${ }^{32}$ dan banyaknya regulasi yang tidak harmonis. ${ }^{33}$

Pembentukan peraturan perundangundangan dengan menggunakan metode Omnibus Law dapat menjadi suatu terobosan hukum terbaik yang dapat ditempuh pemerintah guna mengatasi obesitas regulasi khususnya berkaitan dengan perizinan berusaha. Hal ini bertujuan untuk meningkatkan iklim berinvestasi di Indonesia sebagai upaya pertumbuhan ekonomi. Omnibus Law terkait Cipta Kerja menjadi langkah strategis yang perlu dilakukan oleh pemerintah saat ini untuk mengakomodir kebutuhan hukum yang diiringi oleh proses percepatan berusaha berbasis teknologi.

Hasil penelitian menunjukan bahwa omnibus merupakan metode penyusunan peraturan yang secara luas dan efektif digunakan di negara-negara lain. Kehadiran metode penyusunan peraturan menggunakan omnibus bukan untuk mengganti metode penyusunan peraturan yang telah ada sebagaimana diatur dalam Undang-Undang Nomor 12 Tahun 2011 sebagaimana diubah dengan Undang-Undang Nomor 15 Tahun 2019, melainkan sebagai metode penyempurna. Pada dasarnya, UndangUndang omnibus merupakan peraturan perundang-undangan yang terdiri dari berbagai subjek atau materi pokok yang relevan dan dibentuk guna menyimpangi beberapa norma peraturan sekaligus. Metode ini dinilai mampu mempersingkat proses legislasi dan pembangunan sistem hukum pada umumnya. Namun, harus dipahami bahwa metode penyusunan omnibus merupakan hal baru yang memungkinkan untuk diterapkan di Indonesia.

Undang-Undang dengan metode Omnibus Law menjadi solusi terbaik yang akan mendorong sistem hukum lebih transparan dan berjalan secara lebih efektif dan efisien. Terobosan besar dalam hukum ini, akan menghemat banyak sumber daya karena akan digunakan untuk mengamandemen berbagai aturan hukum. Namun demikian, perlu diperhatikan oleh Pemerintah bahwa mengingat RUU Cipta Kerja (Omnibus Law) mencakup banyak substansi yang diubah, dicabut, atau dibuat pengaturan yang baru, maka sedapat mungkin dapat menjaring berbagai aspirasi dari masyarakat mengenai substansi dari norma yang akan diatur dalam Omnibus Law ini, dalam rangka menjaga kohesivitas antar pemangku kepentingan dalam reformasi regulasi di Indonesia.

\section{Daftar Pustaka}

\section{Buku}

Allison, Graham T, Essence of Decision: Explaining the Cuban Missile Crisis (Boston: MA: Little, Brown, 1971).

Bryan A. Garner, ed., "Black's Law Dictionary", (Minnesota: West Publishing Co, 2004).

Coleman, James C, Problems of Conceptualization and Measurement in Studying Policy Impact, in Public Policy Evaluation, ed. Kenneth M. Dolbeare (Beverly Hills and London: Sage Publications, 1975).

Cook, Thomas D and Donald T. Campbell, QuasiExperimentation: Design and Analysis Issues

32 Okezone, "Rantai Birokrasi Masih Jadi Kendala Investor Berinvestasi di Indonesia", https://economy.okezone. $\mathrm{com} / \mathrm{read} / 2018 / 02 / 12 / 320 / 1858267 /$ rantai-birokrasi-masih-jadi-kendala-investor-berinvestasi-diindonesia (diakses pada 22 Juli 2019).

33 Yayu Agustini Rahayu, "Regulasi Masih Menjadi Kendala Investasi di Indonesia", https://www.merdeka.com/ uang/regulasi-masih-jadi-kendala-investasi-di-indonesia.html (diakses pada 22 Juli 2019). 
for Field Settings (Boston, MA: Houghton Mifflin, 1979).

Dunn, William N, Public Policy Analysis An Integrated Approach (New York: Routledge, 2018).

Johny Ibrahim, Teori dan Metodologi Penelitian Hukum Normatif, (Malang: Bayumedia Publishing, 2006).

Lasswell, Harold D. and Abraham Kaplan, Power and Society: A Framework for Political Inquiry (New Haven, CT: Yale University Press, 1950).

Soerjono Soekanto dan Sri Mamudji, Penelitian Hukum Normatif: Suatu Tinjauan Singkat, Cet. 8 (Jakarta: PT RajaGrafindo Persada, 2006).

Williams, Walter, Social Policy Research and Analysis: The Experience in the Federal Social Agencies (New York: American Elsevier, 1971).

\section{Makalah/Artikel/Prosiding/Hasil Penelitian}

Briana Bierscbach, "Everything You Need to Know About Omnibus Bills, and Why They"re So Popular at The Minnesota Legislature", https:// www.minnpost.com/politics-policy/2017/03/ everything-you-need-know-about-omnibusbills-and-why-theyre-so-popular-minne (diakses pada 22 Juli 2019).Joshua D. Angrist and Jorn-Steffen Pischke, "The Credibility Revolution in Empirical Economics: How Better Research Design Is Taking the Conout of Econometrics", Journal of Economic Perspectives 24, 2 (Spring 2010).

Janet A. Weiss, "Using Social Science for Social Policy", Policy Studies Journal 4 (Spring 1976).

\section{Peraturan}

Indonesia, Peraturan Pemerintah Nomor 24 Tahun 2018 tentang Pelayanan Perizinan Berusaha Terintegrasi Secara Elektronik. (Lembaran Negara Republik Indonesia Tahun 2018 Nomor 90, Tambahan Lembaran Negara Republik Indonesia Nomor 6215 Tahun 2010.

Indonesia, Peraturan Presiden Nomor 91 Tahun 2017 tentang Percepatan Pelaksanaan Berusaha. Lembaran Negara Republik Indonesia Tahun 2017 Nomor 210.

\section{Internet}

Ima Mayasari, "Menggagas Omnibus Law", https://kumparan.com/dr-imamayasari-m-h/menggagas-omnibus- law-1542018891459839175, (diakses pada 22 Juli 2019).

Kontan, "Pemerintah Serahkan Surat Presiden dan Draft Omnibus Law RUU Cipta Kerja ke DPR", http://www. nasional.kontan.co.id/ news/pemerintah-serahkan-surat-presidendan-draf-omnibus-law-ruu-cipta-kerja-ke-dpr (diakses tanggal 15 Februari 2020).

OECD, "Ringkasan Eksekutif Kajian OECD mengenai Reformasi Regulasi Indonesia Memperkuat Koordinasi dan Menghubungkan Pasar", https://www.oecd.org/gov/regulatory-policy/ executive\%20summary\%20INDO\%20with\%20 cover\%20for\%20Internet.pdf (diakses tanggal 17 Agustus 2019).

OECD, "Regulatory Reform and Innovation", http://www.oecd.org sti/inno/2102514.pdf (diakses tanggal 15 Februari 2020).

Okezone, "Rantai Birokrasi Masih Jadi Kendala Investor Berinvestasi di Indonesia", https://economy.okezone.com/ $\mathrm{read} / 2018 / 02 / 12 / 320 / 1858267 / \mathrm{rantai}-$ birokrasi-masih-jadi-kendala-investorberinvestasi-di-indonesia (diakses pada $22 \mathrm{Juli}$ 2019).

Pradany Hayyu, "Sinyal Baik dalam Kemudahan Berusaha", Mediakeuangan (VOL. XIII / NO. 128 / Mei 2018). The World Bank, "Ease of Doing Business Rankings", https://www. doingbusiness.org/en/rankings (diakses tanggal 15 Februari 2019).

Tempo, "Sulitnya Berinvestasi di Indonesia", http://www.kolom.tempo.co/read/1143060/ sulitnya-berinvestasi-di-indonesia (diakses tanggal 15 Februari 2020).

The World Bank, "Doing Business Measuring Business Regulations", https://www. doingbusiness.org/ (diakses tanggal 17 Agustus 2019).

World Economic Forum, "The Global Competitiveness Report 2019", http:// w w w 3 . we for um . org/docs/WE F_ The GlobalCompetitivenessReport2019. pdf(diakses tanggal 15 Februari 2020).

Yayu Agustini Rahayu, "Regulasi Masih Menjadi Kendala Investasi di Indonesia", https://www. merdeka.com/uang/regulasi-masih-jadikendala-investasi-di-indonesia.html (diakses pada 22 Juli 2019) 